\title{
IT GROUP WORK: UNDERGRADUATE STUDENT PERCEPTIONS
}

\author{
Belle S. Woodward, Southern Illinois University, bellew@siu.edu \\ Julia Colyar, University at Buffalo, jecolyar@buffalo.edu \\ Jeffrey F. Woodward, Jeffrey.Woodward@us.army.mil
}

\begin{abstract}
Abstract: This article describes a quantitative study of university students' perceptions of collaborative learning opportunities. Two cohorts of university students were surveyed: students enrolled at a US institution, and students enrolled at a German university. Results indicate that German students value collaborative learning experiences more than their US counterparts.
\end{abstract}

\section{INTRODUCTION}

Preparing today's graduates for the global job market requires teaching technical skills, but also collaborative work values, the "soft skills" workplaces require. Students need to develop critical thinking and communication skills, and they need to be able to work independently as well as in teams. Over the last generation, collaborative learning has been an important pedagogical strategy in higher education classrooms [2]. More recently, computersupported learning has expanded opportunities for students to participate in collaborative experiences [10]. A great deal of research has looked at the affects of collaborative learning opportunities, both for traditional classroom-based projects and computer-based (asynchronous) work $(3,4,5,15]$. Few studies, however, have focused on student perceptions of group work. This study is aimed at understanding how students understand and perceive the benefits of collaborative learning opportunities.

In this paper, we present the findings from a quantitative study of two student populations: students enrolled at a U.S. university, and a cohort of German university students. While the study is not intended as comparative research, we are interested in the differences between the groups of students. Ultimately, results from the cohort of German students helps us understand the data gathered from U.S. students in different ways. In the next sections, we provide a brief literature related to collaborative learning. We then discuss the survey and methodology, and we conclude with implications and discussion.

\section{Collaborative Learning}

While collaborative learning has been researched extensively in elementary and secondary classrooms, it has only recently been the focus of higher education research [3, 11]. Gokhale [5] provides a basic definition: "the grouping and pairing of students for the purpose of achieving an academic goal" (p. 22). However, the process of collaborative learning is much more complex. Collaborative learning has its foundations in developmental psychology. The work of Vygotsky [13, 14], for example, has been instrumental in conceptualizing learning as connected to interaction and activity. According to Vygotsky, students perform at higher levels when they work in diverse groups, as opposed to working individually. Bruffee [2] notes: "knowing is not an unmediated, direct relationship between the subject and object. It is a disjunctive, mediated process involving the agency of other people...there is always another person - or several other peopledirectly or indirectly involved" (p. 137). In the case of the college classroom, "others" in the learning process include both faculty and peers. Faculty, however, serve primarily as facilitators rather than as "authorities" $[2,4,8]$. Students in these contexts are empowered to problem solve, think critically, and develop interpersonal skills [3]. The small group provides a kind of safe space in which students can develop these skills with the support of their peers.

Collaborative learning also requires a restructuring of classroom time and space [3,4]. Rather than relying on lectures, university faculty redesign classroom time for project-based or problem-based learning; students sit in groups rather than in rows facing an instructor. In this restructured classroom space, students can literally "see" the distribution of classroom leadership. Such classroom changes not only help develop small-group communities, but also help develop an institutional learning community [1]. Faculty, however, have an important role in the collaborative process. Faculty provide structure to the learning activity, intervene when students encounter problems, and provide important evaluative feedback [7]. 
A substantial amount of literature has evidenced the benefits of collaborative learning opportunities for postsecondary students. Cabrera et al [3] point out the centrality of the college classroom in influencing students' motivational, and affective development ( $\mathrm{p}$. 20), not simply their cognitive development. Research, however, does indicate that collaborative work helps increase students' learning [5, 15]. Researchers have also discussed the importance of collaborative learning opportunities for student retention, achievement, self-esteem, and developing peer networks [8]. Cabrera et al [3] also notes that collaborative learning supports students' openness to diversity and civic mindedness.

Recent scholarship has explored the use of computersupported collaborative learning opportunities $[9,10$, 12]. This type of group learning takes place via online networks rather than in face-to-face interactions. Students may be located on a campus, or may be engaged in distance learning activities. Lipponen [10] notes that computer-supported learning opportunities "break down the physical and temporal barriers for schooling by removing time and space constraints" (p. 76). In this way, learning environments are further redesigned. Lipponen argues that delays in communication because of the computer environment provides students time for reflection that can enhance their understandings. As students integrate variety of perspectives and develop their own, they can ultimately learn more.

A related body of literature suggests that current undergraduates are more inclined toward group projects and developing teamwork. The "Millennial Generation," according to Howe and Strauss [6], gravitate toward group learning and group activities, and even welcome group grading. Unlike the generation of students before them, current undergraduates seek collaborative learning opportunities.

Computer supported collaborative learning has been studied in a variety of disciplines, but it has particular relevance for students in information technology classrooms. For IT students, collaborative learning activities provide opportunities for exploring content and process. Few studies, however, explore students' perceptions of collaborative learning opportunities.
This study is aimed at further understanding collaborative learning (and computer-supported learning communities) by looking at IT student attitudes about their group assignments and activities. This study included a survey of two groups of students: students enrolled at a large, public Midwest university as IT majors; and IT students enrolled at a public German university. In particular, this study explores the questions: What are IT students' attitudes about collaborative work? How are US students' attitudes different from German students' attitudes? As indicated above, this survey is not intended to compare students in these different contexts. Rather, results from the cohort of German students is intended to help the researchers think about the data collected from US students.

\section{METHODOLOGY}

After an extensive review of the literature, one survey instrument was designed to evaluate the students enrolled in classes in an information technology major at a university in the Bavarian region of Southeastern Germany and a Midwestern university in the United States.

The purpose of the study was to ascertain IT student perceptions related to their experiences in the class doing group work. The purpose and procedures of the survey were explained to the students by the same faculty member for both sites. This included stating that their participation was voluntary and all information was anonymous (with no names on the surveys).

In order to gather data regarding views of US and German students concerning group work in IT classrooms, a researcher-designed survey was administered to two groups of students: one during summer 2008 to predominantly German IT $(\mathrm{n} 1=56)$ and one to US IT students during fall 2008 semester $(\mathrm{n} 2=113)$. The survey questions were forced choice, Lickert-scale with some designed to be open-ended. Questions focused on student participants' perceptions of group work assigned, coached, organized and led by instructors, perceptions of the group work experience, preference for group work versus individual work, and value of the group work evaluation process to the individual.

The survey was administered and monitored by the same researcher for both locations. The paper-pencil formatted survey was completed by both groups in a postsecondary classroom setting. The participants were allowed 30 minutes to complete the survey. At 
the end of the time period, the surveys were collected and given directly to the researcher. Sample questions are included in Appendix A.

Student results were combined for review and separated by country of origin to give researchers the unique opportunity to identify trends gathered from two locations with significant geographic dispersion.

The data were entered into SPSS and analyzed using descriptive statistics, principal component factor analysis, and MANOVA. Results from the analyses are included below.

\section{RESULTS}

The statistical analyses are based on a sample of 103 IT students enrolled at a U.S. university, (male $=89$, female $=14$ ) and a cohort of 56 German university IT students $($ male $=41$, female $=15$ ). The average age for all students is 22.6 with 29 female and 130 male students. This sample has 2 freshmen, 7 sophomores, 78 juniors, and 72 seniors.

A factor analysis of the survey responses was performed to ascertain if the questions in the survey instrument measure unobservable constructs. To explore the dimensionality of the 17 survey questions, factor analysis steps were performed. Principal component factor analysis with Promax rotation (because those factors are assumed to be correlated) was conducted using the correlation matrix of the 17 (question 5-21) variables as input. Principal component analysis yielded four factors with eigenvalues greater than 1 , accounting for about $59 \%$ of total variance.

Table 1 presents the principal component analysis for the four components and Table 2 presents the Factor Correlation Matrix.

\begin{tabular}{|l|c|c|c|c|}
\hline & \multicolumn{4}{|c|}{ Component } \\
\hline & 1 & 2 & 3 & 4 \\
\hline Q5 & & & .730 & \\
Q6 & .724 & & & \\
Q7 & .683 & & & \\
Q8 & .332 & .443 & & -.583 \\
Q9 & .775 & & & \\
Q10 & .553 & & -.431 & \\
Q11 & .655 & & & \\
Q12 & & & & .508
\end{tabular}

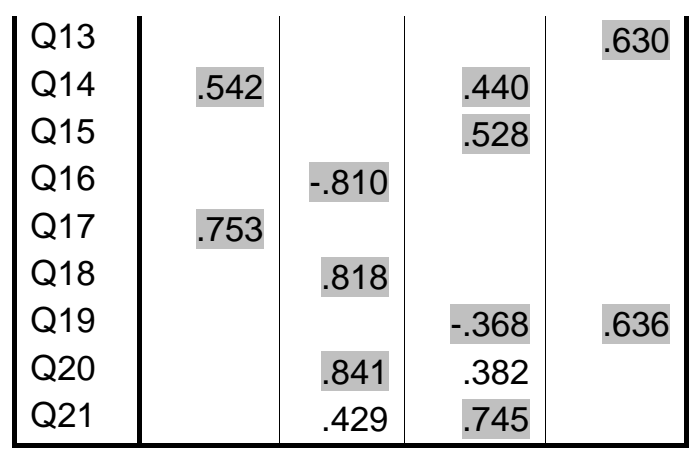

Table 1 Principal Component Analysis

\begin{tabular}{|l|r|r|r|c|}
\hline Component & \multicolumn{1}{|c|}{1} & \multicolumn{1}{c|}{2} & \multicolumn{1}{c|}{3} & \multicolumn{1}{c|}{4} \\
\hline 1 & 1.000 & .264 & .024 & -.065 \\
2 & .264 & 1.000 & .207 & -.083 \\
3 & .024 & .207 & 1.000 & -.017 \\
4 & -.065 & -.083 & -.017 & 1.000 \\
\hline
\end{tabular}

Table 2 Factor Correlation Matrix

As depicted in Table 1 with cut-off point .3 , factor 1 includes questions $6,7,8,9,10,11,14$, and 17; Factor 2 includes questions $8,16,18$, and 20; Questions 5, 10, 14, 15, 19, and 21 are included in factor 3; and Questions 12, 13, and 19 are included in factor 4 .

As a result, the analysis of the responses to the 17 questions in the survey instrument has identified four factors.

The first factor referred to as instructor controls represents students' perception of group work assigned, coached, organized and led by instructors. The second factor, we label as group work represents students' perception of group work experiences. The third factor is named method preference; it represents students' personal preference for group work. The fourth factor we label evaluation method; it represents students' perceptions of how group work was evaluated by the instructor.

Multivariate analysis of variance (MANOVA) was performed using four factors in order to compare US students with German student. The results reveal no significant difference between US and German students on factor \#1 ( $\mathrm{F}=1.29, \mathrm{p}=.258)$ and factor $\# 2(\mathrm{~F}=1.65, \mathrm{p}=.202)$ as indicated in Table 3. This 
informs us that according to student perception, instructors communicate and students receive guidance similarly for group work. The mean score for US students is .06 on Factor \#1 and the mean for German students is .14. Factor \#2 mean score for US students is .07 and .16 for German students.

Significant differences were found between U.S. and German students on factor \#3 mean scores of $\mathrm{F}=$ 40.1 and $\mathrm{p}<.05$ and factor $\# 4 \mathrm{~F}=53.4$ and $\mathrm{p}<.05$ respectively. This indicates German students prefer group work much more than US students. Also, US students prefer one grade for the whole group as compared to German students, who prefer individual evaluations.

\begin{tabular}{|l|l|l|l|l|l|}
\hline $\begin{array}{c}\text { Source } \\
\text { (coun-code) }\end{array}$ & $\begin{array}{l}\text { Type III } \\
\text { Sum of } \\
\text { Square }\end{array}$ & $d f$ & $\begin{array}{l}\text { Mean } \\
\text { Square }\end{array}$ & $F$ & Sig. \\
\hline Factor1 & 1.288 & 1 & 1.288 & 1.29 & .258 \\
\hline Factor2 & 1.638 & 1 & 1.638 & 1.65 & .202 \\
\hline Factor3 & 31.679 & 1 & 31.679 & 40.1 & .000 \\
\hline Factor4 & 39.368 & 1 & 39.368 & 53.4 & .000 \\
\hline
\end{tabular}

Table 3 MANOVA Test Table

\begin{tabular}{|l|l|l|l|l|}
\hline Country & Factor1 & Factor2 & Factor3 & Factor4 \\
\hline $0($ US $)$ & .06 & -.07 & -.31 & .35 \\
$\mathrm{~N}$ & 102 & 102 & 102 & 102 \\
\hline 1 & -.14 & .16 & .69 & -.77 \\
$($ German) & 46 & 46 & 46 & 46 \\
$\mathrm{~N}$ & & & & \\
\hline Total N & 148 & 148 & 148 & 148 \\
\hline
\end{tabular}

Table 4 Factor Score Mean Table

To find if students enjoy group work, a new variable was created by calculating the average for Q5 and Q21. The mean for US students is 2.58 (maximum=4.0) with a $\quad .8$ standard deviation indicating US students prefer individual projects as compared to working in a group. On the other hand, the mean for German students is 3.18 (maximum=4.0) with .54 standard deviation, indicating German students prefer working in a group on projects more than U.S. students.

\section{DISCUSSION}

Results from this study are exploratory and suggest directions for future research. With this study, we do not intend to generalize findings to all US students or German students. Rather, we suggest that collaborative learning opportunities for IT students should be more thoroughly pursued with additional research. Though research suggests that collaborative learning offers positive educational opportunities for students to develop critical thinking skills as well as the interpersonal skills needed in the workplace, US students in this study did not value their collaborative activities. This is particularly interesting given that the current generation of undergraduates is assumed to be both technologically savvy and team oriented. These results suggest that, despite being comfortable in the computing environment, US students prefer individual work and individual grading. German students evidence more positive perceptions of collaborative opportunities.

These results suggest further study in two areas: additional research may explore the different collaborative work students engage in, with particular focus on the types of assignments and content studied. Different content areas and activities may offer different engagement opportunities for students; it is important to know more about the types of activities students pursue so that researchers can understand student perceptions more completely.

In addition, further research should examine the larger educational environments in which students are enrolled. US students in this study may be more likely to work part or full-time, commute from off campus residences, or enroll on a part-time basis. All of these features may influence how students perceive group projects, particularly those pursued outside of class.

In this study, German University campus had a much higher propensity than U.S. students to appreciate assignments where they would have to work in groups after class hours, while U.S. students did not. Again, this may relate to educational environment and student contexts. While the German government subsidizes the majority of university students, U.S. students may spend more of their discretionary time working part time jobs to pay for their education. This information potentially poses enough anecdotal results to a warrant follow up study exploring government financing of education and how it impacts classroom and non-classroom learning experiences for IT students. In addition, future surveys should include demographic and contextual information such as family income, employment (on or off campus), and student housing (on or off campus).

Cultural context may also influence how students perceive group work and should be included in further study. U.S. ideals of rugged individualism and personal values attached to discretionary time may 
collide with a European university climate designed to encourage bi-pedal short transit between university facilities. U.S. campus values for being expansive exacerbated by auto parking accommodation also may discourage meeting in groups after class.

These results are particularly important as IT programs prepare graduates for contemporary workplaces. If students do not value collaborative learning opportunities, it is also possible that they are not adequately prepared-especially in team orientations - to successfully negotiate with others in their professional positions. Further research should explore both the types of team skills that are valued by employers, and the teaching strategies or group work activities that can help develop them in students.

\section{CONCLUSION}

It is important to note that these findings do not contradict previous research which suggests the value of collaborative coursework for the development of critical thinking and interpersonal skills. This study did not seek to explore these outcomes. Rather, this study sought to better understand how students make sense of and value the group work they do in their IT classrooms.

As IT programs and universities generally seek to improve program curriculum and academic outcomes, further examination of IT classroomsincluding how group projects are organized, coached and evaluated - is important. This research suggests that student perceptions do not necessarily align with collaborative learning goals. Further research will be helpful in uncovering the expectations and intentions of IT students as they work toward graduation and the job market. In particular, additional research with students across cultures and contexts will be important. As this study shows, cultural context may be important in understanding how students respond to and engage in collaborative learning opportunities. Additional research may look at other western cultures - Spanish, Italian, or French, for examplebut also non-western societies such as in Asia or Africa. Such inquiry will enable faculty to understand the great diversity of students more completely.

\section{REFERENCES}

1. Astin, A. W. The Changing American College Student: Implications for Educational Policy and Practice. Higher Education. 22: p. 129-143. 1991.

2. Bruffee, K. Collaborative Learning: Higher Education, Interdependence, and the Authority of Knowledge $\left(2^{\text {nd }} e d\right)$. Baltimore: Johns Hopkins University Press. 1999.
3. Cabrera, A.F., Crissman, J.L., Bernal, E.M., Nora, A., Terenzini, P.T., Pascarella, E.T. Collaborative Learning: Its Impact on College Students' Development and Diversity. Journal of College Student Development. 43(1): p. 20-34. 2002.

4. Clifford, V. A. The Development of Autonomous Learners in a University Setting. Higher Education Research and Development., 18(1): p. 115-128. 1999. 5. Gokhale, A.A. Collaborative Learning Enhances Critical Thinking. Journal of Technology Education 7(1): p. 22-30. 1995.

6. Howe, N., \& Strauss, W. Millennials Go To College. Great Falls, VA: LifeCourse Associates. 2007.

7. Johnson, D.W., \& Johnson, R.T. Cooperative Learning and Social Interdependence Theory. In S.R. Tindale \& L. Heath (Eds.), Theory and Research on Small Groups: Social Psychological Applications for Social Issues, Volume 4 (pp. 9-35). New York: Plenum Press. 1998.

8. Johnson, D.W., Johnson, R.T., \& Smith, K.A. Cooperative Learning: Increasing College Faculty Instructional Productivity (ASHE-ERIC Higher Education Report No.4). Washington, DC: George Washington University School of Education and Human Development. 1991.

9. Lehtinen, E., Hakkarainen, K., Lipponen, L., Rahikainen, M., \& Muukkonen, H. ComputerSupported Collaborative Learning: A Review of Research and Development. The J.H.G.I Giesbers Reports on Education, 10. Netherlands: Univesity of Nijmegen, Department of Educational Sciences. 1999.

10. Lipponen, L. Exploring Foundations for Computer-Supported Collaborative Learning. In G. Stahl (Ed.), Computer Support for Collaborative Learning: Foundations for a CSCL Community. Proceedings of the Computer-Supported Collaborative Learning Conference 2002 (pp. 72-81). Hillsdale, NJ: Erlbaum. 2002.

11. Slavin, R.E. Cooperative Learning: Theory, Research and Practice. Englewood Cliffs, NJ: Prentice-Hall. 1990.

12. Soller, A.L. Supporting Social Interaction in an Intelligent Collaborative Learning System. International Journal of Artificial Intelligence in Education, 12: p. 40-62. 2001.

13. Vygotsky, L. S. Thought and Language. Cambridge, MA: MIT press. 1962.

14. Vygotsky, L.S. Mind and Society. Cambridge, MA: Harvard University Press. 1978.

15. Yazici, H.J. Student Perceptions of Collaborative Learning in Operations Management Classes. Journal of Education for Business, (November/December): p. 110-118. 2004. 


\section{Appendix A}

Likert Scale of 1(strongly disagree) to 4 (strongly agree) Maximum mean for each question is 4.0

\begin{tabular}{|c|c|c|}
\hline Sample questions & mean & Standard deviation \\
\hline 5. I enjoy group work when it is assigned in my IT classes & 2.97 & 0.75 \\
\hline $\begin{array}{l}\text { 6. Before starting a group project in my IT class, the instructor provides us with strategies or } \\
\text { advice regarding how to work together }\end{array}$ & 3.00 & 0.595 \\
\hline $\begin{array}{l}\text { 7. Before starting a group project in my IT class, the instructor engages us in lead up activities } \\
\text { to get us accustomed to working together }\end{array}$ & 2.82 & 0.657 \\
\hline $\begin{array}{l}\text { 8. Before starting a group project in my IT class, the instructor provides us with a written } \\
\text { description of the project }\end{array}$ & 3.30 & 0.548 \\
\hline $\begin{array}{l}\text { 9. Before starting a group project in my IT class, the instructor thoroughly reviews with us the } \\
\text { project's evaluation criteria }\end{array}$ & 3.08 & 0.580 \\
\hline $\begin{array}{l}\text { 10. Before starting a group project in my IT class, the instructor provides us with a written } \\
\text { description of the project's evaluation criteria }\end{array}$ & 2.75 & 0.663 \\
\hline $\begin{array}{l}\text { 11. I have received training from my instructor at least once in my IT classes on how to } \\
\text { collaborate as a team or work group }\end{array}$ & 2.60 & 0.694 \\
\hline $\begin{array}{l}\text { 12. When my IT instructor evaluates a group project, he/she awards only one grade to the group } \\
\text { (i.e. each group member receives the same grade regardless the amount of effort or quality of } \\
\text { work submitted by each member) }\end{array}$ & 2.61 & 0.766 \\
\hline $\begin{array}{l}\text { 13. My IT instructors who assign group work should provide a format for students to critique } \\
\text { each group member's contribution to the project }\end{array}$ & 2.97 & 0.665 \\
\hline $\begin{array}{l}\text { 14. During group projects, my IT instructor closely monitors each group's progress during every } \\
\text { class session }\end{array}$ & 2.72 & 0.704 \\
\hline $\begin{array}{l}\text { 15. Whenever my work group encounters difficulties during an IT group project, the instructor } \\
\text { is there to provide guidance }\end{array}$ & 3.27 & 0.592 \\
\hline $\begin{array}{l}\text { 16. In my experience, most IT group projects are completed by one or two individuals, not the } \\
\text { entire group }\end{array}$ & 2.40 & 0.746 \\
\hline 17. My IT instructors provide guidelines for how to effectively complete a group project & 2.86 & 0.594 \\
\hline $\begin{array}{l}\text { 18. In my experience with IT group projects, all tasks are equally distributed among all group } \\
\text { members }\end{array}$ & 2.61 & 0.711 \\
\hline 19. A majority of the IT courses I have taken require at least one group project & 2.89 & 0.787 \\
\hline $\begin{array}{l}\text { 20. In my experience, most IT group projects are collaboratively worked on by all project } \\
\text { members }\end{array}$ & 2.69 & 0.695 \\
\hline $\begin{array}{l}\text { 21. In my IT courses, if given a choice between a group project or an individual project I would } \\
\text { prefer a group project }\end{array}$ & 2.61 & 0.989 \\
\hline
\end{tabular}

